\title{
SOME NOTES ON DIGESTION AND THE CELL STRUC- TURE OF THE DIGESTIVE EPITHELIUM IN INSECTS. (Plate XLI.)
}

\author{
By E. J. Newcomer, Stanford University, California.
}

The ultimate structure of the cell, as it is understood in animal and plant life, is still largely a matter of theory among biologists. A cell appears as a tangible unit, apparently definitely set off from its fellows, and easily discernible with low powers. Yet its exact constitution and its exact relationship to the surrounding cells are not known. So far, scientists have had to imagine how such a structure, with the known functions that it possesses, ought to be composed; it has not yet been possible by actual observation to prove this composition. Many things enter into this difficulty. Cells are very small structures and cannot be viewed with the naked eye. The interposition of a lens or lenses increases the possibility of error. Especially when using lenses of high power is there very little certainty about what is seen. The difficulty of seeing cells in their natural state is great, and resort is had to material that is killed and fixed. Here, even though one is sure of what he sees, he cannot be certain that it is the same as in life. Again, the diversity of cells in different organs and organisms is i1limitable, and it is known that even in the same cell the cytoplasm can change its appearance: so that the problem of getting at the typical and final structure and the behavior of this cytoplasm is by no means an easy one.

It was with the hope of possibly finding out some facts that might have a bearing on the general problem of animal cell structure and behavior that I have undertaken a special study of the make-up and behavior of the digestive epithelium in insects, which study permits me to offer the statements and illustrations embodied in the present paper. The digestive epithelium of insects is notable as a cell layer in which rapid changes occur, with a continual production and destruction of cells. Hence it may be presumed to be a tissue in which cell origin and growth may be advantageously studied. 
Incidentally, the behavior of the digestive canal of insects is only imperfectly known, and though I have nothing to add either to the various cell-structure theories or to the theories concerning digestion, yet these notes recording what seem to be the actual histologic conditions of the digestive epithelium in a number of insects, and suggesting some possible significance of these conditions, may have a little interest.

First, let us take up the matter of cell structure and cell relationship. The old idea that cells were like so many bricks, each to be considered separately, has had to be discarded; and a multicellular organism can no longer be compared to a brick building. At first sight this may seem to be a proper comparison, but reflection will show that the differences are great. For the cells of an organism are by no means constant; they are continually being built up and destroyed. A cell is injured, or it completes the work for which it was created: it disappears, and a new one takes its place. Cell walls are not mere rigid boundaries; they are elastic, permeable, capable of radical change. These things all go hand in hand with a specialization and consequent interdependence of cells, which makes imperative a study of the behavior of many cells rather than of single cells.

A study of insect digestive cells soon makes it apparent that here a definite and constant cell structure does not exist. Digestive cells are extremely active. Two important types of cell secretion may be distinguished, called by Haseman the holocrine and merocrine types. In the former the whole cell contents is discharged at once, and new cells arise. In the latter the discharge is gradual and continuous and the cell remains active for a long period. I shall take up this matter of secretion more fully in connection with the subject of digestion. The important thing here is to note the marked difference in behavior between the two types of cells.

The holocrine type is very well represented by the digestive cells of the dragon-fly (Needham), or by those of almost any predaceous beetle (Fig. 6). Here the cells are formed in nests or nidi, using Needham's term, and gradually develop and increase in size until they are capable of secretion. Upon the introduction of stimulus in the form of food, the largest cells burst, pouring out their contents to mix with the food, and the 
cells in size take their places. Thus we have a regular progression of cells from the very small and scarcely distinguishable ones in the nidi to the full-grown secretive cells. The most interesting point here in connection with the study of cell structure and behavior is the existence of the nidi. What these are and how they originate is a question. They have been variously called "cryptes," "drusenkrypten," and "epithelial buds." None of these terms is very specific, and the idea of these bodies being glandular can hardly be retained, for a gland which secretes nuclei or cells is inconceivable. The nidus appears as a group of nuclei, exactly like those in the fullydeveloped cells except smaller, crowded together, and with very little protoplasm about them. (Figs. 1 and $2, \mathrm{n}$ ). In some instances this group of nuclei is enclosed in a sort of sac protruding out into the muscles surrounding the alimentary canal (Faussek, Frenzel, Rengel), and to this type in particular the term "drusenkrypt" has been applied. More often, however, the nidus is an integral part of the wall of the canal, and there seems to be no special limiting membrane. Are these cell "anlagen" of which the nidus is composed split off from a mother cell? If so, where is this mother cell? Each nucleus of the nidus looks exactly like each other nucleus. Or is the nidus as a whole a cell which produces these nuclei, perhaps by division of its own nucleus? But this approaches the gland idea. As I look at it, it is simply impossible to apply the ordinary theories of cell constitution and cell existence to this structure, this nidus. We must look elsewhere. Mobusz, quoting Adlerz, mentions the presence of a network of protoplasm between the basement membrane and the cell bases, from which new cells arise. We may have to advance a theory of something similar to this to account for the origin of the nuclei in the nidi. If they are not formed by division from others, can they by any possible means be formed from a net of protoplasm? A further and more careful study of these nidi is essential, and will undoubtedly throw light on the general question of cell origin.

Let us turn to the merocrine type of digestive cells, that is, the type where the cell contents is only partly dicsharged as a digestive fluid. This type is to be seen in the alimentary canal of an insect that feeds continuously, thus demanding a con- 
tinuous flow of digestive fluid. Haseman describes the larva of Psychoda as possessing this type of cells. It is also the type present in Lepidopterous larvæ, such as the silkworm (Fig. 11), or in the Coccidæ (Fig. 4), which after once settling down, remain attached to their food-plant, and continuously suck in the plant juices. A study of these cells makes it clear that, although no nests of nuclei are present from which the cells are replaced, nevertheless the cells are replaced. Haseman has very carefully worked this out in the case of Psychoda and finds that the cells are replaced at the molting period. The old cells degenerate and slough off, and new ones, which he calls regenerating cells appear along the basement membrane. Haseman describes the growth of these cells, but makes no attempt to explain their origin. At once Adlerz' notion of a basal protoplasmic network suggests itself. For, to judge from Haseman's drawings the old cells degenerate completely and no part of them composes the new cells, except, as Haseman mentions, that some of the old material may be absorbed by these cells. We must look elsewhere, then, for their origin, and it is not incomprehensible that some sort of basilar protoplasm may exist, from which these cells spring. My preparations of the silkworm are unfortunately not numerous enough to show all stages of this degeneration and replacement, but it seems evident that it takes place here, in a measure as it does in Psychoda. Fig. 7 is from a sagittal longitudinal section of a young silkworm killed just before molting. There are many large, distended cells (d. c.) which appear to be pouring out their whole contents, but as none of these protruding droplets has ever been found detached, it seems more reasonable to suppose that the cells are degenerating, and that the protrusion is an artifact produced by improper killing. Between these cells are others (ab) with a basal nucleus and a clear lumen. This lumen I believe also has been produced artificially, but aside from this these cells are quite different from the others, and may perhaps be absorptive or mucous cells. Along the basement membrane are numbers of small cells (r. c.), each with a nucleus or occasionally two. These cells I take to be the regenerating cells. Fig. 8 shows a cross section near the basement membrane of this same epithelial layer. The three types of cells appear distinctly. 
In Fig. 11 we have in section a portion of the epithelium of a larva that has just molted. Here the large, loosely composed cells are not in evidence, and many of the small basal cells have grown out until they reach the intima. The other type of cell is present also, but is not shown in the drawing. The nodules projecting from the cells here and in Figs. 9 and 10 are interesting in that they seem to have pushed through the intima instead of having stretched it as appears in Fig. 7. They may be artifacts, or more likely they are drops of digestive fluid, such as van Gehuchten has described and figured in Ptychoptera, though I have never found them floating free as he has shown them.

The larva of Dendroctonus, a Scolytid beetle, which burrows into the living wood of pine and other coniferous trees, affords a good example of an insect which feeds continuously, and hence must possess digestive cells which gradually and continuously pour out their secretions. Here the cells are exceedingly regular, each one like the next. There are no nidi to be seen, and no protruding portions are present. The secretion evidently oozes gradually through the intima in small droplets. The only good preparation that I have shows the basal half of these cells to be very compact and darkly staining. while the distal half is open and loose. The nuclei are situated just at the bounadry between these two halves of the cells. This particular larva appears, to judge from the condition of the cuticle, to be upon the point of molting, and this division of the cells may be similar to that which Folsom and Welles. have described in Collembola.

The digestive epithelium of the Coccidæ, as represented by Lecanium, is very simple (Fig. 4). It consists of a row of more or less regular cells, with here and there one which is greatly enlarged. These large ones are evidently the active, secreting cells, while the smaller ones are developing. Frequently these contain two nuclei, indicating that they are formed by direct. division. It would be interesting to see what happens to these cells at molting time, but as the Lecaniums only molt twice (Quayle), and these moltings come while they are still quite small, it would be rather difficult to get preparations.

The digestive phenomena of various insects have been mentioned above briefly and I now propose to take up in order 
the insects I have studied, and give more fully some notes regarding this process, and describing the epithelial cells. I shall consider, first, however, the Isopods, which are not insects but Crustaceans.

Murlin, in an excellent paper on the digestive system of the Isopods, shows that here most of the digestive fluid is secreted in a separate organ, the hepatopancreas, the giant cells of which, however, pour out the secretion in much the same manner as those of the digestive epithelium of many insects. The Isopods have proved to be a very interesting and valuable group with which to begin such a study, both because of the simplicity of their organization, and ease of preparing material, and also because of the very large size of the cells.

The Aptera, the lowest group of insects, will always be the source of a great deal of information regarding digestion, and a thorough study of such forms as Lepisma and Japyx would be valuable. Campodea, I found, has a digestive apparatus very similar to Collembola, as worked out by Folsom and Welles, even down to the apperance of the cells. Japyx (Fig. 1) is quite different. Here the mid-intestinal cells are very open, and have a somewhat alveolar appearance. The cell contents is irregularly granular, and contains numerous large clear vacuoles of varying size, which sometimes compose nearly the entire contents. Here and there are scattered dark granules which probably are concretions. The nuclei are small and basally situated, and stain almost black with iron hæmatoxylin, while in preparations stained with Ehrlich's acid hæmatoxylin they are nearly invisible. The cells evidently arise from nidi, although the latter appear to contain more definite cells than is usual. The intima is very thin, and sometimes slight amounts of secretion may be observed in the digestive lumen along the intima.

Lepisma hàs an extremely interesting digestive system, including a remarkable muscular crop, the posterior end of which protrudes into the mid-intestine. Here the same condition exists which Needham describes as occurring in the Odonata, but in lesser degree (Fig. 2). The active secreting cells, two to four in a group (s. c.) are very sharply marked off from the young, forming cells (y. c.), staining much darker, particularly with the iron hæmatoxylin stain. At the base of 
the lighter cells the nidi (n) are to be found, mere rough groups of nuclei containing each a nucleolus and many granules or perhaps alveoles of varying sizes. The developing cells stain very slightly and frequently contain vacuoles. The active cells are longer, and, on account of the secretion which they contain, stain darkly. Both kinds have a fibrillar or palisadelike appearance basally, which extends as far as the nucleus. The inner portions of the active cells are alveolar, or possibly composed of a network, and contain many small highly refractive concretions. There are no distinct cell walls, but there is a periodical thickening of the fibrils, which give the cells a distinct appearance. The intima is moderately thick and traversed by pore canals. Frequently numerous droplets of secretion (sec) may be seen between this and the peritrophic membrane, and sometimes the secretion appears to be streaming from the active cells. In the region just behind the large crop the cells are smaller and more compact.

The termites have a very peculiar digestive epithelium which perhaps can be correlated with their habit of feeding on dead wood. The stomach is bordered with from ten to twenty lobe-like projections, one of which is shown in Fig. 3. Each of these has at its base a nidus of many nuclei, and extending from this to the inner tip of the lobe, the cells overlap each other in a very curious scale-like manner which is evidently only a variation of the typical holocrine method of cell-formation. It is noteworthy that this method should occur in the termites, which live in the wood they feed upon, and at least have the opportunity of feeding continously, whether they actually do or not.

In the order Hemiptera, I have only studied the rather abnormal Coccidæ (Fig. 4), which I have already mentioned. It looks here as though the large cells discharged their contents and were replaced by the smaller ones, which are formed by simple cell division, though I have not observed the process. In contrast to this arrangement we find in Myrmecophila, a small degenerate cricket (Orthoptera) inhabiting ants' nests (Fig. 5), the typical nidi (n), with the regular wave-like arrangement of nuclei between them. Here, besides the intima with its pore canals, there are what appear to be cilia, and at their ends are small droplets of secretion. 
I have described the appearance of the epithelial cells in one beetle larva, Dendroctonus. Another larva which I have sectioned, that of a Carabid, is entirely different. The cells are arranged in lobe-like groups with a nidus (n) at the base between each two groups, from each side of which the cells arise and gradually grow and migrate until they become fullsized, when the contents is discharged and others replace them. The larger cells are extremely vacuolate, and irregularly granular basally and distally. The nuclei are fairly large and deeply staining.

The Diptera have been studied by various investigators. Van Gehuchten, in his complete work on Ptychoptera, a Tipulid, was one of the first to point out the method of digestive secretion in insects. Haseman's recent paper on Psychoda describes the conditions occurring in another group, with habits not unlike the Tipulids. It is apparent that in larvæ such as these which live practically submerged in their food, the merocrine type of secretion prevails, and the arrangement of the cells secreting in this manner is manifestly entirely different from that representing the holocrine type. This latter, which we have seen in the Carabid larva, and elsewhere, demands cells capable of storing up the digestive fluids until such time as food may be taken into the canal, for predatory insects necessarily get their food irregularly.

The silkworm is distinctly a continuous feeder. Hence we should expect to find no nidi or nuclei present. At first glance it seems otherwise (Fig. 7) but a closer scrutiny reveals the fact that these apparent groups of nuclei are quite different. In the first place there are fewer nuclei in a group than is usual, and then they are strictly not groups of mere nuclei, but groups of small cells. When we realize, too, that this particular insect was just upon the point of molting, we conclude, as I have previously shown, that these are the new cells which form to replace the old ones sloughed off at the molting period.

But let us examine a just-hatched larva, which has taken no food except the portions of the egg-shell devoured in hatching. The cells are exceedingly regular, and none of the small basal cells to be observed. Most of the cells are deeply staining, granular, with an elongate, central, granular nucleus, and distally containing a few small vacuoles. Frequently another type occurs, lighter, more homogeneous, with basal, rounded nuclei. 
These I believe are the absorptive cells and correspond to the cells marked ab. in Fig. 7. Of course this larva has had no plant food yet, but we must suppose that these cells contain something besides food products. As a matter of fact they are much leaner than in older larvæ except for the basal part containing the nucleus, being scarcely distinguishable between the secretory cells. These are beginning to form the secretion, though none of them has any protruding droplets. Larvæ sectioned twenty-four hours after beginning to feed, show some food in the alimentary canal, and some of the secretory cells are giving off small drops of fluid. As the larva grows these droplets increase in size until they appear as in Fig. 10 or 11. The contents of the absorptive cells is homogeneous, and takes the Orange $\mathrm{G}$ stain precisely as does the contents of the silk glands, which indicates that it is a product of digestion, as the liquid silk is merely this same product somewhat transformed. The changes in the cells during molting I have already described.

As a killing fluid I found nothing superior to Carnoy's fluid, which is a mixture of 6 parts of absolute alcohol, 3 parts of glacial acetic acid, and one part of chloroform. For general insect work it is entirely satisfactory. The chloroform very quickly dissolves any wax or grease, and allows the insect to sink. It acts quickly, and is very simple to use. The specimens are merely dropped into it, left for a couple of hours, and transferred to alcohol, first $70 \%$ and then $85 \%$. There was some distortion and occasionally shrinkage, but I am inclined to believe that this latter was due to some fault in the subsequent treatment. Tower's, Gilson's, hot water, etc., gave no better results, and are not so easily handled. I tried injecting a number of silkworms with the killing fluid, just after dropping them into it, but could see no difference between these and those not injected. The specimens were run through alcohol and imbedded in the ordinary way. Sections were cut as thin as possible. I tried a variety of stains and found combinations either of Ehrlich's acid hæmatoxylin or iron hæmatoxylin with Orange $\mathrm{G}$ to be the most satisfactory. Occasional preparations stained with carmine and Orange $G$ brought out points not observable in others. The Orange G is a very desirable secondary stain, as it stains tissues which otherwise would remain almost colorless. 
The work here recorded was done and the paper prepared in the Entomological Laboratory of Stanford University by me as holder of the Bernard Scholarship for 1913-1914 in Insect Histology.

\section{BIBLIOGRAPHY.}

Bernard, H. M. Some Neglected Factors in Evolution. 1911.

Bordas, L. L'Appareil Digestif des Orthoptères, Ann. Sci. Nat. Zool. ser. 8, t. 5, 1898, pp. 1-208, plate.

Cuenot, L. Etudes physiologiques sur les Crustacés Decapodes, Arch. Biol. t. XIII, 1893, pp. 245-303, 2 pl.

Cuenot. Etudes physiologiques sur les Orthoptères. Arch. Biol. t. XIV, 1896 , pp. 293-341, 2 pl.

Eberli, J. Untersuchungen am Verdaungs-traktus von Gryllotalpa vulgaris. Vierteljahrschrift der naturforsch. gesell. in Zurich. 37 Jahrg. 2 Heft, 1892.

Faussek, V. Beitr. z. Histologie des Darmkanals der Insekten. Zeit. wiss. Zool. Bd. 45, 1887, pp. 694-712, 1 pl.

Folsom, J. W. Entomology with Reference to its Biological and Economic Aspects. 2nd. ed., 1913, p. 96, fig. 151.

Folsom, J. W., and Welles, M. U. Epithelial Degeneration, Regeneration, and Secretion in the Mid-Intestine of Collembola. Univ. of I11. Univ. Studies, vol. II, no. 2, 1906 . Plates.

Frenzel, J. Einiges uber den Mitteldarm der Insekten sowie uber Epithel-regeneration. Arch. Mikr. Anat. Bd. 26, 1886, pp. 229-306, 3 taf.

Van Gehuchten, A. Recherches Histologiques sur 1'Appareil digestif de la larve de la Ptychoptera contaminata. La Cellule, t. VI, fasc. 1, 1890, pp. 185-289. Plates.

Van Gehuchten, A. Contribution a I'Etude du Mecanisme de I'Excrétion Cellulaire. La Cellule, t. IX, fasc. 1, 1893, p. 95-116, 1 pl.

Grassi, B. I Progenitori dei Miriapodi e degli Insetti. Reale Ac. dei Liucei. Mem. VII. Anat. Comp. dei Tisan (1888), Acc. Gioenia, Mem III. Anat. Machilis (1885), Acc. Gioenia Mem. III. Anat. Japyx and Campodea (1885). Torino, Morf. Scolopendrella (1885).

Haseman, L. The structure and Metamorphosis of the Alimentary Canal of the Larva of Pyschoda alternata. Ann. Ent. Soc. Am. vol. III, No. 4, 1910, pp. 277-313, 5 plates.

Miall \& Denny. The Cockroach, 1886, pp. 121-122.

Mobusz, A. Ueber den Darmkanal der Anthrenus-Larve, nebst Bemerkungen zur Epithelregeneration. Inaug. Diss. Univ. Leipzig, 1897.

Murlin, J. R. Absorption and Secretion in the Digestive System of the Land Isopods. Proc. Acad. Nat. Sci. Phil. May, 1902.

Needham, J. G. The Digestive Epithelium of Dragon-fly Nymphs. Zool. Bul. vol. 1, No. 2, 1897.

Quayle. H. J. The Black Scale. Cal. Agr. Exp. Sta. Bul. 223, 1911.

Rengel, C. Ueber die Veranderungen des Darmepithels bei Tenebrio molitor wahrend der Metamorphose. Inaug. Diss. Fried. Wil. Univ. Berlin, 1896. 


\section{EXPLANATION OF PLATE XLI.}

(All are camera lucida drawings except Figs. 3, 4 and 5).

Fig. 1. Epithelial cells of mid-intestine of Japyx. Longitudinal section. X 1160.

Fig. 2. Epithelial cells of mid-intestine of Lepisma. Longitudinal section. $\mathrm{X} 1160$.

Fig. 3. One lobe of mid-intestine of termite. Cross section.

Fig. 4. Portion of mid-intestine of Lecanium. Cross section.

Fig. 5. Epithelial cells of Myrmecophila. Cross section. X 760 .

Fig. 6. Epithelial cells of Carabid larva. Longitudinal section. X 760 .

Fig. 7. Portion of mid-intestine of silkworm, just molting. Longitudinal section. X 740 .

Fig. 8. Cross section through same on line A-B, Fig. 7. X 740.

Figs. 9 and 10. Epithelial cells of silkworm. X 720 .

Fig. 11. Portion of mid-intestine of silkworm just after molting. Longitudinal section. $\times 720$.

\section{ABBREVIATIONS.}
ab., absorptive cells.
b. m., basement membrane.
c. m., circular muscles.
con., concretions.
d. c., degenerating cells.
int., intima.
1. m., longitudinal muscles.

n., nidi.

nuc., nuclei.

r. c., regenerating cells.

s. c., secreting cells.

sec., secretion.

vac., vacuoles.

y. c., young cells. 


\section{$2 \mathrm{BHL}$ Biodiversity Heritage Library}

Newcomer, E J. 1914. "Some Notes on Digestion and the Cell Structure of the Digestive Epithelium in Insects. (Plate XLI)." Annals of the Entomological Society of America 7, 311-321. https://doi.org/10.1093/aesa/7.4.311.

View This Item Online: https://www.biodiversitylibrary.org/item/42040

DOI: https://doi.org/10.1093/aesa/7.4.311

Permalink: https://www.biodiversitylibrary.org/partpdf/193648

\section{Holding Institution}

Smithsonian Libraries

\section{Sponsored by}

Smithsonian

\section{Copyright \& Reuse}

Copyright Status: NOT_IN_COPYRIGHT

This document was created from content at the Biodiversity Heritage Library, the world's largest open access digital library for biodiversity literature and archives. Visit BHL at https://www.biodiversitylibrary.org. 